\title{
PENGARUH KETAATAN PADA PRINSIP SYARI'AH (KPS) TERHADAP LOYALITAS NASABAH
}

\author{
Siti Asiyah \\ al.asiyah@yahoo.com \\ STIE Gempol Pasuruan
}

\begin{abstract}
Adherence to theprinciple of Shariais the basis ofthe formation ofcustomer loyalty, butcustomerloyaltydoes not justcome into beingcoupledwith thepositive effortsof a social naturesuch asCSR. Byimplementing CSR, the level ofloyaltyandconsumer confidencewill increase. This research is explanatory research (explanation), the research wants to find an explanation in the form of cause and effect.This study aimed to analyze and test the effect of adherence to Islamic principles on customer loyalty with CSR as a mediation on the BMT Sidogiri East Java.This study was conducted by distributing questionnaires to 136 customers loan recipient qardul hasan BMT Sidogiri located in the branch Pasuruan, Malang, Surabaya and Mojokerto.Sampling was done by sampling purposive. Data analysis method used is the PLS method. The results of this study prove that Obedience On Sharia principles can increase customer loyalty through CSR Sidogiri BMT as mediation.CSR significantly contribute to the improvement of loyalty, not only regarding the fulfillment of the obligations legally, morally and government rules, but also as an application of morality and behavior as a Muslim.
\end{abstract}

Key words: Adherence to theprincipleof sharia, CSR, andcustomerloyalty.

\begin{abstract}
ABSTRAK
Ketaatan pada Prinsip Syari'ah (KPS) merupakan dasar terbentuknya loyalitas nasabah, akan tetapi loyalitas nasabah tidak begitu saja terbentuk tanpa dibarengi dengan upaya-upaya positif yang bersifat sosial seperti CSR. Dengan menjalankan CSR, tingkat loyalitas konsumen akan meningkat. Jenis penelitian ini merupakan penelitian explanatory (penjelasan), yaitu penelitian yang ingin mencari penjelasan dalam bentuk sebab akibat. Penelitian ini bertujuan untuk menganalisis dan menguji pengaruh ketaatan pada prinsip syari'ahterhadap loyalitas nasabah dengan CSR sebagai mediasi pada BMT Sidogiri Jawa Timur. Penelitian ini dilakukan dengan cara menyebarkan kuesioner kepada 136 orang nasabah penerima pinjaman qardul hasan BMT Sidogiri yang berada di cabang Pasuruan, Malang, Surabaya dan Mojokerto. Pengambilan sampel dilakukan dengan sampling purposive. Metode analisis data yang digunakan adalah metode PLS. Hasil penelitian ini membuktikan bahwa Ketaatan pada Prinsip Syari'ah dapat meningkatkan loyalitas nasabah BMT Sidogiri melalui CSR sebagai mediasi. CSR secara nyata memberikan kontribusi dalam peningkatan loyalitas, bukan hanya menyangkut pemenuhan kewajiban secara hukum, moral dan aturan pemerintah, tetapi juga sebagai aplikasi akhlaq dan perilaku sebagai seorang muslim.
\end{abstract}

Kata kunci: ketaatan pada prinsip syari'ah, CSR, dan loyalitas nasabah.

\section{PENDAHULUAN}

Keberadaan bank syari' ah yang semakin hari semakin meningkat ini, masih belum bisa menyentuh masyarakat kecil atau pengusaha kecil yang tidak bankable, karena untuk meminjam di bank syari'ah, nasabah terkendala oleh persyaratan administrasi yang diminta bank antara lain; harus memiliki jaminan, SIUP maupun NPWP. Ketatnya persyaratan ketika meminjam di bank syari'ah inilah menyebabkan masyarakat dan pengusaha kecil tidak terlayani oleh bank syari'ah. BMT yang merupakan salah satu LKMS dianggap lebih mengena di kalangan masyarakat dan pengusaha kecil daripada bank syari'ah karena lebih fleksibel 
dalam persyaratan dan jumlah pinjaman maupun keluwesan pada pencairan kredit (Hascaryani et al., 2011).

Ada beberapa faktor yang berpengaruh terhadap cerahnya prospek perkembangan perbankan syari'ah, dimana ini juga bisa dibuat acuan oleh BMT, karena BMT mempunyai prinsip yang sama dengan bank syari'ah antara lain; (1) tingkat kesadaran umat Islam tentang bisnis syari'ah, (2) kualitas SDM di bidang perbankan syari'ah, (3) minat para investor untuk membuka divisi syari'ah, (4) adanya payung hukum yang jelas dan (5) kondisi iklim perekonomian Indonesia. Pendapat ini sesuai dengan (Sjahdeini, 1999), yang mengatakan bahwa tingginya respon terhadap bank Islam dipicu oleh ketidakpuasan terhadap konsep dan operasi bank konvensional. Perbedaan pandangan bahwa bunga bank itu riba juga mempengaruhi respon masyarakat terhadap LKMS (BMT). Pandangan ini sesuai dengan hasil penelitian dari (Sejati, 2006) yang menunjukkan, bahwa pandangan masyarakat tentang bunga bank adalah haram atau syubhat berpengaruh positif dan signifikan terhadap probabilitas masyarakat untuk menabung pada bank syari'ah. Larangan riba ini, menjadikan kebutuhan masyarakat akan perbankan syari'ah atau lembaga keuangan mikro syari'ah (LKMS) seperti BMT semakin tinggi. Realitas inilah yang menjadikan bahwa perbankan syari'ah (BMT) harus ada.

Islam melarang umatnya meminjamkan uang dengan mengambil bunga, pengambilan keuntungan hanya diperbolehkan dalam hal perdagangan (Rivai, 2012). Dasar pertimbangannya bahwa terhadap saudara yang miskin harus saling membantu dan berbagi bukan malah merugikan, apalagi membebani pinjamannya dengan bunga, sungguh ini perbuatan dosa dan dilarang keras oleh agama Islam. Hal ini sesuai dengan firman Allah yang termaktub dalam surat al-Hadid ayat 11; yang menganjurkan kepada umat Islam untuk selalu berbuat kebaikan, terutama ketika saudaranya membutuhkan yaitu dengan memberi pinjaman tanpa bunga. Selanjutnya (Sadeq, 1992) mengatakan bahwa bunga merupakan suatu bentuk ketidakadilan karena memberikan diskriminasi terhadap pembagian resiko maupun untung. Sistem bunga akan membatasi investasi, karena tingkat bunga berhubungan negatif dengan investasi.

Perkembangan BMT yang pesat akhirakhir ini harus diikuti dengan layanan yang berbeda ala syari'ah; yaitu strategi yang tepat pada kesamaan jenis layanan yang ditawarkan oleh suatu perusahaan adalah strategi yang mempunyai keunggulan kompetitif yang berkelanjutan, seperti usaha yang sulit ditiru dan mempunyai keunggulan yang tidak dimiliki oleh pesaingnya. Adapun pemasaran yang berorientasi pada konsumen, adalah pemasaran yang selalu memberikan sesuatu yang terbaik bagi konsumennya, seperti memberikan modal bagi pengusaha kecil yang menjadi tujuan sosialnya. Harapan penganut Islam terhadap organisasi yang mengaku Islam sudah jelas, bank Islam diharapkan mampu menjalankan tanggung jawab lembaga terhadap masyarakat (CSR) untuk mendapatkan legitimasi terhadap kelanjutan eksistensinya (Lewis, 2001, dan Maali, 2003).

Dari hasil penelitian di atas, diketahui bahwa salah satu permasalahan yang ada pada BMT pada rendahnya loyalitas nasabah. Permasalahan lain adalah kurangnya program-program berbagi seperti CSR, dan ketaatan pada prinsip syari'ah yang masih tidak sesuai dengan harapan nasabah. Penggunaan responden pada nasabah pembiayaan qardul hasan dalam penelitian ini dirasa tepat, karena nasabah pembiayaan merupakan orang yang telah menikmati "program-program CSR" dan dianggap lebih mengetahui seberapa jauh prinsip syari'ah telah dijalankan secara benar dalam BMT Sidogiri dibanding dengan nasabah pendanaan.

Adapun permasalahan yang harus dijawab dalam penelitian ini adalah: Bagaimanakah pengaruh Ketaatan Pada prinsip Syari'ah (KPS) pada loyalitas nasabah BMT Sidogiri di Jawa Timur dengan CSR sebagai 
mediasi dan bagaimana pula pengaruh langsung CSR terhadap loyalitas nasabah BMT Sidogiri di Jawa Timur? Tujuan dari penelitian ini adalah untuk menganalisis dan menguji pengaruh ketaatan pada prinsip syari'ah terhadap loyalitas nasabah dengan CSR sebagai mediasi dan pengaruh langsung CSR terhadap loyalitas nasabah pada BMT Sidogiri di Jawa Timur.

\section{TINJAUAN TEORETIS}

\section{Ketaatan Pada Prinsip Syari'ah (KPS)}

Ketaatan pada prinsip syari'ah (KPS) merupakan suatu bentuk komitmen atau kepatuhan manusia kepada perintahperintah atau larangan-larangan Allah yang didasarkan pada Al-Qur'an dan Hadist. Ketaatan pada prinsip syari'ah (KPS) merupakan syarat mutlak yang harus dipenuhi oleh lembaga keuangan yang menjalankan usahanya berdasarkan prinsip syari'ah, dikarenakan KPS merupakan perwujudan dalam pemenuhan seluruh prinsip syari'ah pada semua aktivitas usaha suatu lembaga keuangan, sehingga dapat mencerminkan karakteristik dari lembaga itu sendiri, termasuk BMT. Semua hubungan, baik hubungan dengan Tuhannya maupun dengan sesama manusia dalam Islam harus didasarkan pada Al-Qur'an dan Hadist. Hal ini menyiratkan bahwa dalam setiap tindakan atau kegiatan yang dilakukan manusia di bumi ini harus berdasarkan pada AlQur'an dan Hadist. Ajaran Islam tidak boleh hanya dipandang sebagai hal yang bersifat ritual, tetapi harus diimplementasikan pada setiap kegiatan yang dilakukan oleh manusia. Demikian pula dengan urusan muamalah atau perekonomian, juga harus tunduk pada prinsip-prinsip syari'ah yang telah diatur berdasarkan Al-Qur'an dan Hadist.

Menurut Abdullah dan Chee (2012), suatu kegiatan muamalah yang berdasarkan prinsip syari'ah, yaitu kegiatan muamalah yang menghindari tiga larangan mendasar dari keuangan syari'ah yaitu:

a. Riba (bunga); Riba mencakup segala imbal hasil uang atas uang, baik bunga itu tetap atau mengambang, sederhana atau majemuk, dan pada tingkat suku bunga berapapun.

b. Gharar (ketidakpastian); Yaitu transaksi yang objeknya tidak jelas, tidak dimiliki, tidak diketahui keberadaannya, atau tidak dapat diserahkan pada saat transaksi dilakukan kecuali diatur lain dalam syari'ah.

c. Maisir (judi); bersifat spekulasi, dimana kedua belah pihak tidak mempunyai informasi yang jelas terhadap sesuatu yang diperdagangkan sehingga bisa merugikan salah satu pihak.

Dengan demikian, yang dimaksud dengan ketaatan pada prinsip syari'ah adalah ketaatan BMT menjalankan operasional usahanya dengan tetap berpegang teguh pada prinsip-prinsip syari'ah seperti menghindari riba, gharar dan maisir, dimana implementasinya yaitu dengan jalan menerapkan akad-akad sesuai dengan prinsip syari'ah seperti; akad musyarakah dan mudharabah, ijarah dan qardul hasan (pinjaman kebajikan) dalam penyaluran dana.

Dengan melihat beberapa pendapat di atas, maka bisa ditarik suatu kesimpulan bahwa ketaatan pada prinsip syari'ah (KPS) adalah merupakan hal yang membedakan LKMS (BMT) dengan LKM konvensional.

\section{Corporate Social Responsibility (CSR) (1) Konsep CSR}

Secara konseptual, teori CSR yang digunakan dalam penelitian ini mengacu pada konsep sustainable development (pembangunan berkelanjutan) dengan menggunakan metode triple bottom line yang dikembangkan oleh Elkington (1997) dalam bukunya berjudul "Canibals with Forks, the Triple Bottom Line of Twentieth Century Bussines." Dalam konsep Triple Bottom Line ditegaskan bahwa perusahaan yang ingin terus sustainable dalam kancah persaingan, perlu mempelajari dan memahami aspek 3P; yaitu perusahaan tidak semata-mata memperhatikan profit, tetapi perusahaan mempunyai kewajiban peduli dan aktif dalam memberdayakan masyarakat (people) sekitarnya serta ikut dalam pelestarian lingkungan (planet). 
Dalam konsep $3 \mathrm{P}$ ini, perusahaan tidak boleh hanya memikirkan perusahaan dari aspek keuangan saja tetapi harus menyeimbangkan faktor lain seperti planet dan people untuk keberlanjutan kehidupan di dunia. Konsep ini digambarkan melalui segitiga dalam kehidupan stakeholders yang mesti diperhatikan perusahaan di tengah upayanya mencari profit (ekonomi), yakni lingkungan dan sosial.

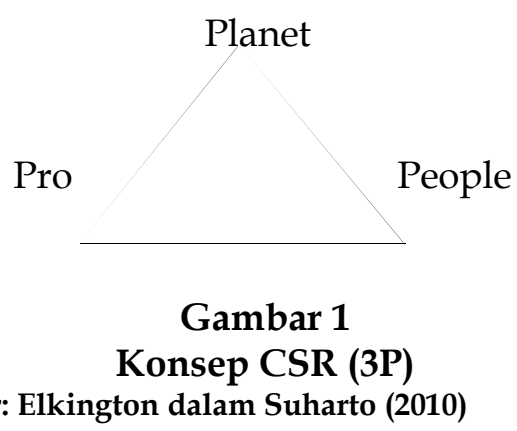

Dengan demikian, perilaku atau cara perusahaan memperhatikan dan melibatkan shareholder, pekerja, pelanggan, pemasok, pemerintah, LSM, lembaga internasional dan stakeholder lainnya merupakan konsep utama CSR. Lebih jauh, CSR adalah operasi bisnis yang berkomitmen tidak hanya untuk meningkatkan keuntungan perusahaan se cara finansial, melainkan pula untuk pembangunan sosial-ekonomi secara holistik, melembaga, dan berkelanjutan.

Selanjutnya CSR merupakan investasi bagi perusahaan untuk mendorong pertumbuhan berkelanjutan. CSR bukan lagi dilihat sebagai sentra biaya, melainkan sebagai sentra laba dimasa yang akan datang (Alma; 2009). Menurut World Business Council for Sustainable Development dinyatakan dalam buku CSR oleh Wibisono (2007); CSR merupakan suatu komitmen berkelanjutan oleh dunia usaha untuk bertindak secara etis dan memberikan kontribusi kepada pengembangan ekonomi dari komunitas setempat ataupun masyarakat secara luas, bersamaan dengan peningkatan taraf hidup pekerjanya beserta seluruh keluarganya. Schernerhorn dalam (Suharto; 2009), CSR adalah suatu kepedulian organisasi bisnis untuk bertindak dengan cara-cara mereka sendiri dalam melayani kepentingan organisasi dari kepentingan public eksternal. Lebih jauh dikatakan bahwa, CSR merupakan cita-cita perwujudan tanggung jawab sosial perusahaan dalam bentuk tindakan yang berdasarkan etika dengan tujuan untuk meningkatkan ekonomi secara berkelanjutan disertai peningkatan kualitas hidup karyawan beserta keluarganya sekaligus peningkatan kualitas hidup masyarakat ser dan masyarakat pada umumnya.

\section{(2) CSR dalam Perspektif Islam}

CSR dalam pandangan Islam merupakan sesuatu yang sudah seharusnya melekat pada LKM syari'ah (BMT), karena BMT mempunyai tujuan untuk kemaslahatan bagi orang banyak. Konsep CSR adalah konsep saling berbagi, atau saling membantu antar sesama dengan harta atau profit yang dimiliki oleh perusahaan. Konsep ini sesuai dengan konsep BMT yang mempunyai tujuan untuk kemaslahatan orang banyak. BMT tidak hanya mempunyai tujuan ekonomis tetapi juga mempunyai tujuan sosial yang salah satunya adalah berbagi yang dalam Islam biasa disebut dengan kewajiban membayar zakat, sumbangan (waqof), sedekah, pinjaman bebas bunga (qardul hasan) (Sadeghzadeh, 1995). Pendapat ini menegaskan bahwa pemberian zakat, waqof, sedekah dan pinjaman kebajikan (pinjaman bebas bunga) termasuk dalam konsep CSR. Hal ini sesuai dengan konsep berbagi dari CSR.

Larangan terhadap riba juga muncul dari prinsip-prinsip keadilan sosio ekonomi dalam Islam di mana tujuannya adalah melarang beberapa distribusi kekayaan tidak adil melalui kerugian dipaksa pada satu pihak atau keuntungan yang tidak dapat diperoleh pada pihak lain (bunga tetap). Didasarkan pada latar belakang tersebut dapat disimpulkan bahwa norma dan nilai bisnis Islam konsisten dengan definisi CSR. Hal ini diperkuat dengan aturan yang ada dalam Al-Qur'an yang memuat tentang amwaal (kepemilikan, kekayaan dan semua harta benda dalam segala bentuknya). Ada- 
pun aturan-aturan yang menyangkut tentang kekayaan dapat dilihat dalam surat AlBaqarah: 215. Ayat ini menjelaskan bahwa seseorang tidak boleh hanya memikirkan dirinya sendiri, tetapi dia mempunyai kewajiban untuk membantu orang lain terutama orang miskin. Hal ini dikarenakan, sebagai manusia yang beriman, manusia mempunyai kewajiban membangun keadilan sosial dan ekonomi agar tercipta keseimbangan hidup di dunia dan di akhirat, yang mana itu merupakan tujuan hidup seorang muslim. Dengan demikian, konsep CSR yang berbagi sudah seharusnya melekat pada BMT, yang dalam operasional usahanya berdasarkan pada nilai-nilai Islam (prinsip syari'ah).

CSR termasuk dalam permasalahan etika bisnis, ketika berbisnis haruslah diikuti dengan tanggung jawab sosial kepada orang lain. Inilah pandangan Islam terhadap etika bisnis. Berkaitan dengan konsep tanggung jawab sosial juga, BMT berkewajiban memberdayakan masyarakat sekitar dengan memberikan pinjaman kebajikan (qardul hasan) kepada rakyat kecil atau pengusaha kecil guna meningkatkan taraf hidup dan kesejahteraan mereka. Pinjaman kebajikan ini diberikan murni berdasar amal dan sodaqah BMT kepada mereka yang membutuhkan, sehingga pemberian pinjaman kebajikan ini bersifat produktif. Lebih jauh pinjaman ini tidak dikenai bunga (bebas bunga) sehingga peminjam hanya mengembalikan sejumlah modal yang diterimanya, jadi tidak ada kelebihan/penambahan pembayaran. Inilah konsep hutang-piutang yang diajarkan dalam Islam. Tambahan penghasilan (keuntungan) hanya diperkenankan melalui perniagaan atau perdagangan, sedangkan dalam hal pemberian hutang, lebih mengedepankan aspek sosial.

Hal ini sesuiai dengan pendapat dari Suharto (2010), yang mengatakan bahwa CSR Islami pada hakekatnya mengedepankan pemberdayaan berbasis syari'ah. Adapun pendekatan yang bisa diterapkan dalam CSR Islami salah satunya adalah pemberian qardul hasan, yakni program pemberian modal yang diangsur tanpa penambahan apapun dan tujuannya untuk pemandirian usaha. CSR merupakan amal dari masyarakat termasuk perusahaan yang benarbenar disisihkan dari keuntungan yang didapatkan dan bukan dari menekan konsumen, dimana hal itu untuk kemaslahatan orang banyak terutama orang tidak mampu atau miskin. Untuk lebih memperjelas hubungan antara CSR dan pengembangan masyarakat yang sesuai dengan perintah agama, maka bisa dilihat Gambar 2.

\section{Loyalitas Pelanggan}

Lembaga Keuangan Mikro Syari'ah sebagai perusahaan yang bergerak di bidang jasa, sangat perlu meningkatkan loyalitas nasabah dengan memberikan sesuatu yang bisa menarik hati nasabah dengan cara yang tidak semata-mata untuk meningkatkan profit, tetapi yang lebih bersifat tindakan sosial seperti CSR dan ketaatan pada prinsipprinsip syari'ah yang menjadi dasar operasionalnya. Keadaan ini menuntut BMT melakukan strategi yang tidak hanya bersifat ekonomis, tetapi lebih dituntut bersifat sosial, karena nasabah sekarang lebih pintar dan paham terhadap perilaku yang seharusnya dilakukan oleh sebuah BMT.

Jadi, untuk meningkatkan loyalitas, maka BMT perlu menerapkan strategi yang benar-benar bisa menyentuh hati nurani masyarakat khususnya nasabah, yaitu dengan memberikan zakat, amal, infaq dan shodaqoh seperti yang diperintahkan dalam ayat-ayat Al-Qur'an dan Hadist. Lebih jauh Islam menjelaskan bahwa loyalitas berkaitan erat dengan halal-haramnya suatu produk/ jasa yang ditawarkan, sehingga untuk kasus pemilihan lembaga keuangan tentunya konsumen dalam memilih lembaga tersebut juga akan mempertimbangkan hal tersebut.

Ini sesuai dengan anjuran dalam QS. AlMaidah: 91 yang menjelaskan bahwa sebagai umat Islam tidak boleh berjudi dan minum-minuman keras karena akan menjauhkan dalam mengingat Allah. 


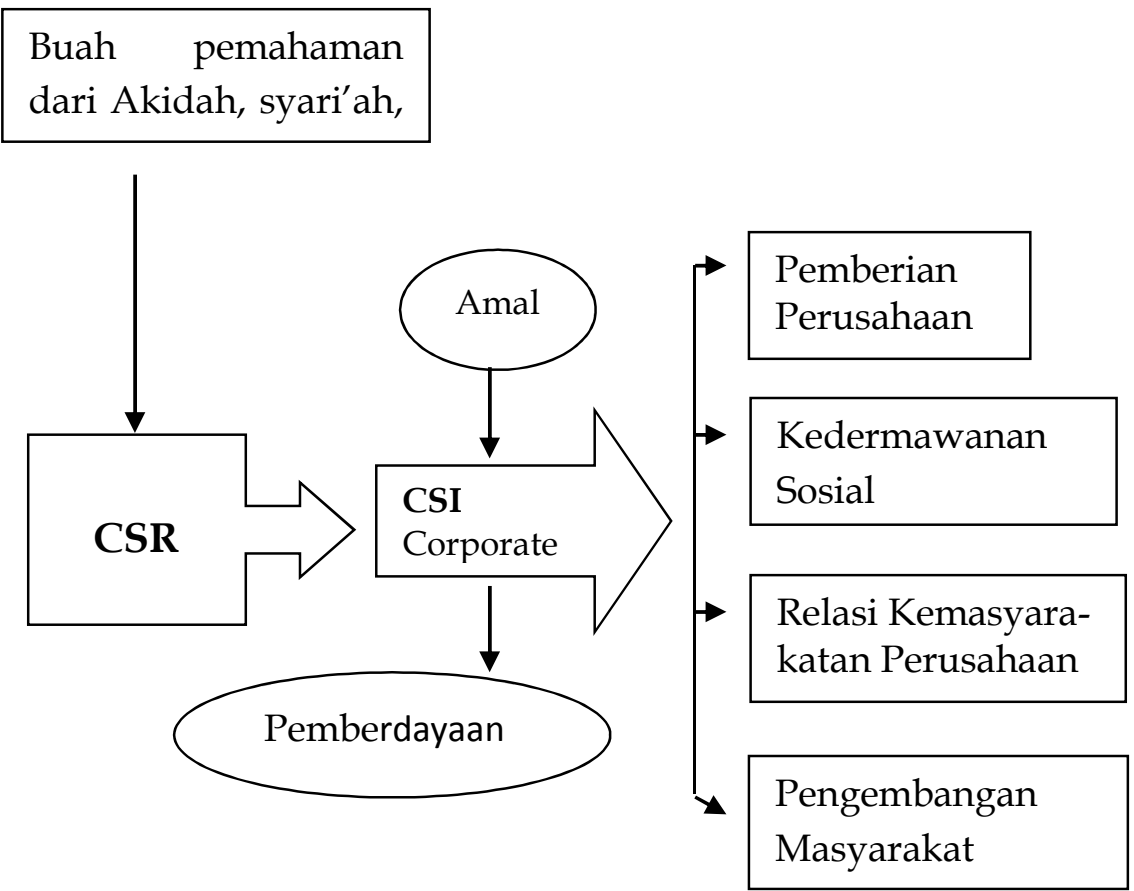

Gambar 2

Hubungan antara CSR dan Pengembangan Masyarakat sesuai perintah agama Sumber: Alma dan Soeharto (2009)

Demikian juga dalam hal perdagangan seharusnya menghindari hal-hal yang haram seperti riba, gharar dan maysir, karena itu bisa menimbulkan kemudharatan di dunia, seperti yang telah dijelaskan pada uraian sebelumnya, oleh karena itu untuk meningkatkan loyalitas nasabah muslim, pelaku bisnis perlu memahami syariat Islam atau larangan-larangan yang ada dalam AlQur'an. Dengan demikian produk atau jasa yang ditawarkan dapat diterima oleh konsumen muslim.

Tjiptono (2000) juga menjelaskan beberapa karakteristik dari pelanggan yang loyal, diantaranya 1) Melakukan pembelian ulang yang konsisten; 2) Merekomendasikan produk perusahaan kepada orang lain dan 3) Konsumen tidak mudah beralih pada produk pesaing. Menurut Olson (1996), loyalitas pelanggan merupakan dorongan perilaku untuk melakukan pembelian secara berulang-ulang dan untuk membangun kesetiaan pelanggan terhadap suatu produk/jasa yang dihasilkan oleh badan usaha tersebut membutuhkan waktu yang lama melalui suatu proses pembelian yang berulang-ulang tersebut.

Membangun loyalitas pelanggan merupakan kebijakan strategis bagi perusahaan. Perusahaan memandang loyalitas pelanggan merupakan bagian dari strategi perusahaan dalam menghadapi pesaing dan menghubungkan perusahaan dengan pasar (konsumen). Pfeifer dan Farris (2006) mengidentifikasikan loyalitas pelanggan sebagai jaminan keuntungan jangka pendek dan jangka panjang bagi perusahaan.

Berdasarkan beberapa definisi dari loyalitas di atas, maka dalam penelitian ini menggunakan dimensi loyalitas berdasarkan Tjiptono (2000) yang menjelaskan beberapa karakteristik dari pelanggan yang loyal, diantaranya adalah:

1. Melakukan transaksi ulang yang konsisten Pelanggan menggunakan kembali produk/jasa yang sama yang ditawarkan perusahaan.

2. Merekomendasikan produk perusahaan kepada orang lain. Pelanggan melakukan komunikasi dari mulut ke mulut 
berkenaan dengan produk/jasa tersebut kepada orang lain.

3. Konsumen tidak mudah beralih pada produk/jasa pesaing. Pelanggan tidak tertarik terhadap tawaran produk/jasa sejenis dari pesaing dan akan senantiasa memakai produk/jasa tersebut.

\section{Hasil Penelitian Terdahulu}

Penelitian dari Metawa dan Almossawi (1997) mengindikasikan bahwa keputusan seleksi bank yang dibuat konsumen adalah didominasi oleh pertimbangan religius. Kepatuhan terhadap prinsip Islam didapati sebagai kriteria seleksi yang paling penting, yang diikuti oleh tingkat return. Hal inilah yang menjadi dasar pada penelitian sekarang untuk menguji pengaruh variabel ketaatan pada prinsip syari'ah terhadap loyalitas nasabah bank.

Penelitian dari Omer (1992) terhadap 300 muslim di Inggris menunjukkan, bahwa alasan agama merupakan motivasi utama bagi muslim di Inggris untuk memilih lembaga keuangan Islam. Lebih jauh penelitian Hegazy (1995) menyimpulkan bahwa kebanyakan nasabah bank Islam adalah Muslim yang memilih untuk mematuhi hukum Islam.

Temuan penelitian ini menunjukkan bahwa sebagian besar dari konsumen menjalin hubungan dengan bank Islam karena alasan religius, yaitu karena bank Islam menjalankan prinsip-prinsip syari'ah. Bahkan tiga alasan utama dari sebagian besar responden bisa dipandang sebagai alasan religius, karena bank Islam beroperasi sesuai dengan ajaran Islam, maka bank Islam memiliki reputasi yang baik dan menjaga keyakinan klien di dalam masalah operasi dan pengungkapan informasi. Di sisi lain, alasan konvensional untuk menjalin hubungan dengan sebuah bank, seperti laba, tidak banyak mendapatkan dukungan dari para responden. Mereka yang menjalin hubungan dengan bank Islam siap untuk menerima berapapun return yang diberikan asalkan bank mematuhi prinsip-prinsip syari'ah dan mereka mempercayai bank Islam untuk mengelola dana mereka dan sekaligus menjalankan ajaran agama.

Penelitian dari Fatmah (2009) menjelaskan bahwa antara persepsi religiusitas dan kepercayaan, persepsi religiusitas dan loyalitas serta kepercayaan dan loyalitas terbukti terdapat hubungan positif dan signifikan. Berdasarkan hasil penelitian ini, maka dalam penelitian ini menguji, hubungan antara ketaatan prinsip syari'ah dengan loyalitas dengan menggunakan CSR sebagai mediasi. Dari hasil penelitian ini bisa dijelaskan, bahwa untuk menghalangi berpindahnya nasabah ke bank (BMT) lain maka bank (BMT) harus melakukan tindakan yang konkrit dalam meningkatkan loyalitas nasabah, misal dengan menjalankan program CSR yang bisa meningkatkan loyalitas nasabah terhadap BMT.

Hasil penelitian dari Poolthong et al. (2009), menunjukkan bahwa inisiatif CSR mempunyai peranan penting dalam perceived service quality, dimana pada gilirannya mempengaruhi trust dan brand effect dan temuan terakhir, CSR berpengaruh secara langsung terhadap brand effect. Hal ini menunjukkan bahwa CSR memang bisa dijadikan sebagai alat strategi pemasaran utamanya untuk meningkatkan persepsi positif nasabah terhadap sebuah bank (BMT) sebagai salah satu LKMS. Bila nasabah telah mempunyai persepsi positif pada bank (BMT), maka pada gilirannya akan semakin meningkatkan loyalitas nasabah. Penelitian yang sedang dilakukan sekarang juga akan menguji lebih dalam tentang hubungan antara KPS dan CSR terhadap loyalitas nasabah BMT.

Niatan pembelian ulang didapati memiliki hubungan signifikan dan positif dengan persepsi kualitas layanan. Persepsi kualitas layanan juga didapati memberikan kontribusi bagi kesetiaan sikap. CSR terbukti memiliki hubungan positif dan signifikan dengan kesetiaan sikap dan persepsi kualitas layanan. Inisiatif CSR tidak memiliki dampak langsung terhadap niatan pembelian ulang pada bank-bank utama dari para responden, dan inisiatif CSR cenderung 
untuk memiliki hubungan yang lebih kuat dengan peningkatan dalam persepsi kualitas layanan dan kesetiaan sikap.

Hal ini menunjukkan bahwa CSR tidak bisa secara langsung mempengaruhi niatan untuk membeli kembali, tetapi perlu dimediasi oleh persepsi kualitas layanan, ini berarti bahwa CSR itu bersifat memberikan penguatan terhadap persepsi dan sikap konsumen yang nantinya bisa mendorong kepada kesetiaan sikap yang pada akhirnya akan menciptakan keinginan untuk membeli kembali, karena CSR dianggap mempunyai nilai-nilai yang bisa membawa kebaikan terhadap konsumen dan masyarakat. Selain itu temuan ini juga mengindikasikan, bahwa CSR akan direspon positif oleh konsumen kalau kualitas pelayanan yang diberikan oleh BMT dianggap handal (memuaskan) atau sesuai dengan harapan yang diinginkan oleh konsumen. Berkaitan dengan hasil penelitian tersebut, maka peneliti menilai bahwa loyalitas nasabah dapat ditingkatkan dengan adanya KPS dan pelaksanaan CSR terhadap sebuah jasa keuangan. Dari dua penelitian yang telah dilakukan oleh Poolthong et al. (2009 dan 2011), maka ini membuktikan bahwa KPS bisa meningkatkan loyalitas dengan mediasi CSR.

\section{Hipotesis Penelitian}

Bagian ini menggambarkan model hipotesis dari pengaruh ketaatan pada prinsip syari'ah terhadap loyalitas nasabah dengan CSR sebagai variabel mediasi.

\section{Pengaruh KPS terhadap loyalitas nasabah dengan CSR sebagai mediasi}

Penelitian dari Metawa dan Almossawi (1997) menunjukkan bahwa faktor yang mendapatkan peran penting terbesar dalam proses seleksi bank adalah faktor religius, yaitu kepatuhan terhadap prinsip Islam. Temuan ini mengindikasikan bahwa bankbank Islam memiliki basis kekuasaan yang relatif kuat di kalangan konsumen yang mementingkan kepatuhan terhadap prinsipprinsip Islam di dalam institusi finansial yang mereka pilih.
Selanjutnya Naseret al. (1999) mengatakan, bahwa 70 persen sepakat atau sangat sepakat dengan pendapat bahwa alasan religius memiliki peran penting di dalam memilih bank Islam. Ini dilanjutkan dengan 65 persen dari responden yang memiliki hubungan dengan bank Islam karena bank Islam tidak hanya sekedar menyediakan layanan perbankan konvensional tapi mematuhi prinsip-prinsip syari'ah. Lebih jauh Ajmi (2009) menemukan bahwa: keyakinan agama Islam dan tanggung jawab sosial adalah dua faktor penting yang menentukan pilihan bank.

Sejumlah ayat dalam Al-Qur'an dan hadist nabi menetapkan apa yang harus dilakukan agar membangun keadilan sosio ekonomi dengan bertanggung jawab secara sosial. Beberapa contohnya adalah kewajiban membayar zakat, sumbangan (waqof), sedekah, pinjaman bebas bunga (Sadeghzadeh, 1995) dalam Farouk (2011).

Keberagaman (religiusitas) diwujudkan dalam berbagai aspek kehidupan manusia. Aktifitas beragama tidak terjadi hanya ketika seseorang melakukan perilaku ritual saja. Akan tetapi diapresiasikan ke dalam kehidupan sosial kemasyarakatan, termasuk praktek perbankan sebagai bagian dari muamalah ekonomi. Nasution (1973) dalam Muclis (2011), menyebutnya sebagai internalisasi nilai-nilai ajaran agama yang diyakini tidak mustahil dan tidak bertentangan dengan logika yang kemudian diekspresikan dalam kehidupan sosial kemasyarakatan. Dengan demikian religiusitas mencakup keadaan yang terdapat dalam diri seseorang yang mendorongnya berpikir, bersikap, bertingkah laku, dan bertindak sesuai dengan ajaran agamanya.

Didasarkan pada latar belakang tersebut dapat disimpulkan bahwa norma dan nilai bisnis Islam konsisten dengan definisi CSR. Selanjutnya, ajaran-ajaran agama yang telah dipahami dapat menjadi pendorong kehidupan individu dalam berinteraksi dengan Tuhan dan sesama manusia, bahkan dengan alam (Mehboob ul Hassan, 2007). Sifat kepatuhan terhadap prinsip-prinsip 
dan hukum Islam dari sudut pandang Islam memandang tidak saja sebagai jaminan kepatuhan terhadap penerbitan laporan syari'ah, tetapi juga keterlibatan lebih besar dalam aktivitas CSR termasuk pengungkapan CSR (Farook et al., 2011). Peranan bank dalam menciptakan kesempatan kredit bagi seluruh entrepreneur kecil dipandang sebagai satu aspek penting dalam mengembangkan masyarakat.

Selanjutnya, dibuktikan oleh penelitian ini bahwa jumlah bank di Timur Tengah dan Asia Selatan telah menggunakan aspek pertanggungjawaban sosial dalam operasi mereka sebagai aplikasi dari prinsip-prinsip Islam.
Komitmen kuat Islam terhadap keadilan dan persaudaraan menuntut bahwa organisasi bisnis harus memperhatikan orangorang yang membutuhkan. Amal dalam Islam adalah satu-satunya kebajikan yang sangat dihargai oleh umat manusia (Hassan et al., 2009). Maka;

$\mathrm{H}_{1}$ : KPS berpengaruh positif terhadap loyalitas nasabah dengan CSR sebagai mediasi dengan penjelasan sebagai berikut:

$\mathrm{H}_{1} \mathrm{a}$ : KPS berpengaruh positif terhadap loyalitas nasabah

$\mathrm{H}_{1 \mathrm{~b}}$ : KPS berpengaruh positif terhadap CSR

$\mathrm{H}_{1} \mathrm{C}$ : CSR berpengaruh positif terhadap loyalitas nasabah

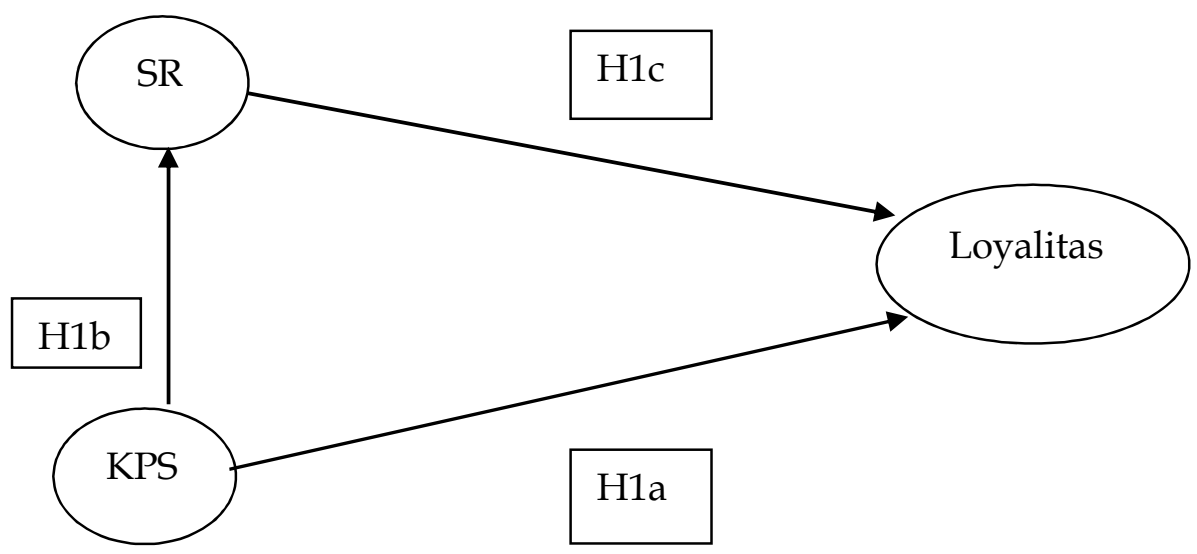

\section{Gambar 3 \\ Model Penelitian}

\section{METODE PENELITIAN}

Jenis penelitian ini merupakan penelitian explanatory (penjelasan), yaitu penelitian yang bertujuan untuk menjelaskan hubungan sebab akibat antara beberapa situasi yang digambarkan dalam variabel, kemudian ditarik suatu kesimpulan umum. Penelitian ini merupakan penelitian kuantitatif yang bertujuan untuk mengembangkan pengetahuan melalui pengujian terhadap hipotesa yang diajukan, melakukan pengukuran dan observasi, serta menguji suatu teori. Penelitian ini menggunakan sampling purposive yaitu teknik penentuan sampel dengan pertimbangan tertentu. Adanya keterbatasan peneliti dalam meneliti semua cabang BMT Sidogiri berada, maka lokasi dipilih mengacu pada keberadaan Bank Indonesia yang ada wilayah Jawa Timur dan berdasarkan pada cabang yang dapat memberikan pinjaman qardul hasan yang tinggi mencapai Rp.2.000.000,- dan termasuk cabang yang jumlah nasabah qardul hasannya terbanyak. Adapun urutan cabang BMT Sidogiri yang mempunyai nasabah terbesar adalah cabang Pasuruan, Malang, Surabaya dan Mojokerto (informasi bagian pemasaran).

Populasi sasaran dalam penelitian ini adalah seluruh nasabah pembiayaan qardul hasan Baitul Maal wat Tamwil (BMT) Sidogiri yang berada di Jawa Timur. Teknik pengambilan sampel dalam penelitian ini adalah non probability sampling dikarenakan 
yang menjadi obyek penelitian ini adalah nasabah yang menerima pinjaman kebajikan (qardul hasan) dari BMT Sidogiri dan jumlahnya tidak diketahui secara pasti karena bersifat rahasia, dan nasabah tidak mempunyai tabungan di lembaga keuangan yang lain.

Berdasarkan pertimbangan estimasi kemungkinan maksimum, jumlah sampel sebesar 80 sudah dapat memberikan hasil yang valid, tetapi jumlah sampel sekecil ini tidak direkomendasikan dan ukuran sampel minimum yang tepat dalam penelitian adalah minimum 100 responden Hair et al. (1992). Berdasarkan pendapat tersebut, jumlah sampel dalam penelitian ini ditetapkan sebanyak 200 orang nasabah, untuk mengantisipasi kuesioner tidak kembali atau tidak layak untuk dilakukan pengujian lebih lanjut.

Kuesioner diisi oleh nasabah pembiayaan qardul hasan BMT Sidogiri di Jawa Timur yang berada di cabang Pasuruan, Malang, Surabaya dan Mojokerto. Dalam memilih nasabah yang menjadi sampel dilakukan dengan metode Judment sampling (pertimbangan tertentu) dengan kriteria sebagai berikut: (1) Nasabah yang menerima pinjaman kebajikan (qardul hasan) dariBMT Sidogiri JawaTimur; (2) Minimal telah menjadi nasabah BMT Sidogiri selama 1 tahun; (3) Nasabah hanya mempunyai tabungan di BMT Sidogiri, ketika penelitian ini dilakukan; (4) Ditemui di lokasi penelitian.

Alat pengumpulan data pada penelitian ini adalah kuesioner yang akan diberikan kepada responden. Kuesioner ini berisi sejumlah daftar pertanyaan/pernyataan tertulis dimana responden diminta untuk menjawab atau memberikan tanggapan atas apa yang telah mereka rasakan dan harapkan sesuai dengan kenyataan yang ada.

Pengukuran skor untuk item-item pertanyaan terhadap permasalahan yang diteliti menggunakan skala Likert, satu sampai dengan lima tingkatan skala yang menghasilkan respon terhadap sebuah stimuli yang disajikan dalam bentuk kategori yang menyatakan sebuah sikap atau keterangan tertentu dari responden Ferdinand (2011). Kriteria pernyataan positif dalam variabel penelitian adalah $1=$ sangat tidak setuju, $2=$ tidak setuju, $3=$ netral, $4=$ setuju, $5=$ sangat setuju.

\section{Definisi Operasional Variabel}

Ketaatan pada prinsip syari'ah adalah ketaatan pada aturan perjanjian berdasarkan hukum Islam antara BMT Sidogiri dengan nasabah pembiayaan yang menerima pinjaman kebajikan, dimana pelaksanaannya harus memenuhi prinsip-prinsip syari'ah, seperti tidak mengandung unsur Riba (bunga bank), Gharar (untung-untungan) dan Maysir (Judi) yang dilarang dalam akadakad keuangan Islami.

\section{Indikator ketaatan pada prinsip syari'ah adalah :}

1. Larangan Riba, yaitu larangan penambahan pendapatan secara tidak sah antara lain dalam transaksi pertukaran barang sejenis yang tidak sama kualitas, kuantitas, dan waktu penyerahan, atau dalam transaksi pinjam-meminjam yang mempersyaratkan nasabah penerima fasilitas mengembalikan dana yang diterima melebihi pokok pinjaman karena berjalannya waktu;

2. Larangan Gharar, yaitu larangan transaksi yang obyeknya tidak jelas, tidak dimiliki, tidak diketahui keberadaannya, atau tidak dapat diserahkan pada saat transaksi dilakukan kecuali diatur lain dalam syari'ah;

3. Larangan Maysir, yaitu larangan transaksi yang digantungkan kepada suatu keadaan yang tidak pasti dan bersifat untung-untungan. Atau, meminjam uang untuk berspekulasi pada pergerakan mata uang.

\section{Corporate Social Responsibility (CSR)}

Corporate Social Responsibility (CSR) merupakan kegiatan BMT Sidogiri dalam memberikan kredit atau modal usaha dalam bentuk pinjaman kebajikan (qardul hasan) 
untuk memberdayakan masyarakat kecil/ tidak mampu serta membina hubungannya dengan nasabah. Indikator CSR adalah sebagai berikut: Bravo, et al., 2009.

1. Pinjaman kebajikan; pemberian kredit tanpa bunga untuk tujuan produktif yang diberikan BMT Sidogiri pada masyarakat yang membutuhkan seperti orang miskin dan pengusaha kecil,

2. Hubungan dengan konsumen; usahausaha BMT Sidogiri dalam menjaga hubungan baiknya dengan nasabah dan hak-hak nasabahnya.

\section{Loyalitas Nasabah}

Loyalitas nasabah adalah sikap positif dan komitmen nasabah terhadap BMT Sidogiri, untuk tetap meneruskan hubungan dan menggunakan jasanya di masa yang akan datang (adanya transaksi yang berulang kali).

Indikator untuk mengukur loyalitas nasabah diadaptasi dari Peter dan Olson (1996) dan Tjiptono (2000) yaitu:

1. Transaksi ulang yaitu keinginan nasabah untuk tetap menggunakan dan menambah transaksi dengan BMT Sidogiri pada waktu yang lain.

2. Memberikan informasi pada orang lain yaitu rekomendasi dan promosi produk dari nasabah BMT kepada nasabah lainnya.

3. Ketahanan untuk tidak berpindah pada bank lain, yaitu keinginan nasabah untuk tetap setia menjadi nasabah BMT.

\section{Uji Validitas dan Reliabilitas}

Berdasarkan uji validitas, seluruh item penelitian diperoleh nilai probabilitas semua item kurang dari 0,05 dan seluruh nilai korelasi ( $\mathrm{r}$ hitung) lebih besar dari $\mathrm{r}$ tabel $(\mathrm{r}$ hitung $>0,355$ ) sehingga disimpulkan bahwa semua pertanyaan pada masing-masing variabel Ketaatan pada Prinsip Syari'ah, CSR, dan Loyalitas telah valid.

Hasil pengujian reliabilitas menunjukkan bahwa nilai koefisien reliabilitas masingmasing variabel Ketaatan pada Prinsip Syari'ah, CSR, dan Loyalitas lebih besar dari
0,6. Jadi, bisa disimpulkan bahwa pertanyaan pada masing-masing variabel Ketaatan pada Prinsip Syari'ah, CSR, dan Loyalitas dapat diandalkan (reliabel).

\section{Teknik Analisis Data}

Teknik analisis data dalam penelitian ini menggunakan Partial Least Square (PLS). PLS digunakan, karena dalam penelitian ini menggunakan teori berdasar Al-Qur'an yang tidak bersifat universal, maksudnya kebenarannya hanya diakui oleh orang Islam (muslim) saja. Dengan demikian, penggunaan PLS dirasa tepat. Alasan lain dari penggunaan teknik ini adalah, PLS tidak menganjurkan sampel besar maupun banyak asumsi, sehingga dipandang lebih unggul dibanding SEM. Selain itu PLS juga bisa digunakan pada variabel yang bersifat reflektif maupun formatif, sehingga PLS bisa dikatakan lebih bagus daripada SEM. Dan yang terakhir PLS mempunyai kegunaan untuk eksplanasi, prediksi, konfirmasi maupun untuk mengembangkan teori.

\section{ANALISIS DAN PEMBAHASAN}

Hasil Pengujian koefisien jalur dan pengaruh langsung dapat dijelaskan sebagai berikut:

$\mathrm{H}_{1 \mathrm{a}}$ : Terdapat hubungan langsung antara KPS dengan loyalitas nasabah

Hasil pengujian pengaruh ketaatan pada prinsip syari'ah terhadap loyalitas dapat dibuktikan dengan nilai estimate koefisien jalur sebesar 0,173, dengan arah positif. Koefisien jalur bertanda positif memiliki arti hubungan antara ketaataan pada prinsip syari'ah dengan loyalitas nasabah adalah searah. Dengan menggunakan taraf signifikansi 0,05 diperoleh $t$ tabel sebesar 1,96 dan ini menunjukkan bahwa nilai $t$ hitung sebesar 1,551 lebih kecil dari pada $t$ tabel. Analisis ini memberikan keputusan bahwa koefisien regresi tersebut adalah tidak signifikan. Hasil pengujian ini menjelaskan bahwa semakin tinggi ketaatan BMT pada prinsip syari'ah, tidak secara otomatis meningkatkan tingkat loyalitas nasabah. Artinya, ketaataan pada prinsip 
syari'ah yang baik belum berpengaruh nyata terhadap tingginya loyalitas nasabah, dalam artian masih ada variabel lain selain ketaatan pada prinsip syari'ah yang dapat meningkatkan loyalitas nasabah secara langsung atau secara cepat. Hasil penelitian ini tidak mendukung adanya pengaruh langsung dari ketaatan pada prinsip syari'ah terhadap loyalitas nasabah.

$\mathrm{H}_{1 \mathrm{~b}}$ : Terdapat hubungan langsung antara KPS dengan CSR

Berdasarkan hasil analisis data diperoleh bahwa nilai estimasi koefisien jalur pengaruh langsung ketaataan pada prinsip syari'ah terhadap CSR sebesar 0,543, dengan arah positif. Koefisien jalur bertanda positif memiliki arti hubungan antara ketaataan pada prinsip syari'ah dengan CSR adalah searah. Hasil ini dapat pula dibuktikan dengan nilai titik kritis sebesar 6,977. Dengan menggunakan taraf signifikansi 0,05 diperoleh $t$ tabel sebesar 1,96 dan ini menunjukkan bahwa nilai $t$ hitung lebih besar dari pada $t$ tabel. Analisis ini memberikan keputusan bahwa koefisien regresi tersebut adalah signifikan. Hasil ini memberikan kesimpulan bahwa data hasil penelitian mendukung adanya pengaruh langsung dari ketaatan pada prinsip syari'ah terhadap CSR. Hasil pengujian membuktikan semakin tinggi ketaatan BMT pada prinsip syari'ah, semakin besar/baik pula CSR yang diberikan oleh BMT Sidogiri. Artinya, ketaataan pada prin- sip syari'ah yang baik akan berpengaruh nyata terhadap besarnya CSR yang diberi- kan oleh BMT, sehingga hasil ini didukung oleh fakta empiris pada obyek penelitian ini.

$\mathrm{H}_{1 \mathrm{c}}$ : Terdapat hubungan antara CSR dengan loyalitas nasabah

Berdasarkan hasil analisis data diperoleh bahwa nilai estimasi koefisien jalur pengaruh langsung CSR terhadap loyalitas nasabah sebesar 0,322 dengan arah positif. Koefisien jalur bertanda positif memiliki arti hubungan antara CSR dengan loyalitas adalah searah. Hasil ini dapat pula dibuktikan dengan nilai titik kritis sebesar 2,536. Dengan menggunakan taraf signifikansi 0.05 diperoleh $t$ tabel sebesar 1,96 dan ini menunjukkan bahwa nilai $t$ hitung lebih besar dari pada $t$ tabel. Analisis ini memberikan keputusan bahwa koefisien regresi tersebut adalah signifikan. Hasil ini memberikan kesimpulan bahwa data hasil penelitian mendukung adanya pengaruh langsung dari CSR terhadap loyalitas. Hasil pengujian membuktikan semakin besar CSR yang diberikan BMT, semakin tinggi pula loyalitas nasabah pada BMT Sidogiri. Artinya, semakin baik pelaksanaan CSR pada BMT Sidogiri akan berpengaruh nyata terhadap tingginya loyalitas nasabah, sehingga hasil ini didukung oleh fakta empiris pada obyek penelitian ini.

Tabel 1

Hasil Model PLS

Hasil Pengujian Pengaruh Langsung antar variabel

\begin{tabular}{cccccc}
\hline \hline & $\begin{array}{c}\text { Original } \\
\text { Sample } \\
\text { Estimate }\end{array}$ & $\begin{array}{c}\text { Mean of } \\
\text { subsamples }\end{array}$ & $\begin{array}{c}\text { Standard } \\
\text { deviation }\end{array}$ & t-statistic & Ket \\
\hline KPS -> Loyalitas & 0.173 & 0.187 & 0.112 & 1.551 & $\begin{array}{c}\text { Tidak } \\
\text { Signifikan }\end{array}$ \\
CSR -> Loyalitas & 0.322 & 0.308 & 0.127 & 2.536 & Signifikan \\
KPS -> CSR & 0.543 & 0.555 & .0078 & 6.977 & Signifikan \\
\hline
\end{tabular}

Sumber: Hasil Olahan PLS, Tahun 2015 
Pengaruh Ketaatan pada prinsip syari'ah (KPS) terhadap loyalitas nasabah dengan CSR sebagai mediasi

Pada penelitian ini, CSR merupakan variabel penting sebagai mediasi pengaruh KPS terhadap loyalitas nasabah karena KPS yang tinggi akan dicerminkan oleh kemampuan KPS dalam meningkatkan CSR, misalnya semakin baik KPS yang dijalankan oleh BMT, tentunya akan semakin bagus pelaksanaan CSR yang ada pada BMT tersebut. CSR yang berbentuk pinjaman kebajikan dan hubungan baik dengan konsumen inilah yang mendorong nasabah untuk berperilaku loyal terhadap BMT Sidogiri. Hasil penelitian ini sesuai dengan hasil penelitian dari (Sulayman, 1976); (Sadeghzadeh, 1995); (Fatmah, 2009) dan (Farook, 2011) yang mengatakan bahwa sifat kepatuhan terhadap prinsip-prinsip dan hukum Islam dari sudut pandang Islam memandang tidak saja sebagai jaminan kepatuhan terhadap penerbitan laporan syariah, tetapi juga keterlibatan lebih besar dalam aktivitas CSR termasuk pengungkapan CSR. Dalam Islam, amal adalah satu-satunya kebajikan yang sangat dihargai oleh umat manusia. Allah akan mencabut berkah dari riba, tetapi akan meningkatkan berkah dari amal (Hadist Muslem). Temuan ini sesuai dengan janji Allah SWT seperti yang difirmankan dalam Al-Qur'an surat alHadad ayat 11:

"Barang siapa yang meminjami Allah pinjaman yang baik, Allah akan melipat gandakan baginya dan di sisi-Nya pahala berlimpah dan lebih mulia."

Dan ini menjelaskan bahwa amal baik seperti memberikan hutang tanpa bunga akan mendapat keberkahan, dimana keberkahan yang dapat dirasakan oleh BMT Sidogiri sekarang adalah loyalitas yang tinggi dari nasabahnya. Lebih jauh, aturanaturan yang menyangkut tentang kekayaan dapat dilihat dalam surat Al-Baqarah: 215: Ayat diatas membuktikan bahwa Al-Qur'an itu benar adanya karena Al-Qur'an merupakan pedoman hidup umat manusia khususnya umat Islam yang datang dari Allah, sehingga siapapun yang berbuat baik akan mendapat ridho dari Allah SWT sesuai janjinya dalam Al-Qur'an. BMT Sidogiri mendapatkan keberkahan dari CSR yang dilakukannya dengan penuh keikhlasan dan kerja keras tanpa mengenal lelah berupa loyalitas nasabah yang tinggi. Kalau hal ini dihubungkan dengan penilaian responden terhadap loyalitas nasabah BMT yang sebagian besar telah memberikan penilaian baik khususnya indikator ketahanan untuk tidak berpindah pada BMT lain dengan nilai 4,07 .

Demikian pula dengan nilai estimasi loading yang memiliki nilai tertinggi juga sama yaitu ketahanan untuk tidak berpindah pada BMT lain dengan nilai 0,818 . Hal ini mengindikasikan bahwa dalam pandangan responden indikator ketahanan untuk tidak berpindah merupakan indikator dominan dalam meningkatkan loyalitas, dan indikator ini sejalan dengan apa yang telah dilakukan oleh BMT Sidogiri dalam mempertahankan loyalitas nasabah, seperti tercermin pada kesetiaan nasabah terhadap BMT, meski nisbah bagi hasil kecil dan kecintaan nasabah terhadap seluruh produk-produk BMT.

Dengan modal loyalitas dari nasabah, BMT Sidogiri menjadi BMT yang berkembang pesat sampai wilayah operasinya mencakup wilayah Jawa Timur. Prestasi ini tidak mudah diraih untuk ukuran lembaga keuangan kecil yang berbasis syari' ah seperti BMT yang dalam operasionalnya memang melayani masyarakat menengah bawah dan usaha kecil. Akan tetapi kesuksesan ini tercapai berkat do'a dari para nasabah dan orang-orang di sekitarnya yang telah menikmati CSR, hasil penelitian ini sesuai dengan penelitian dari (Siswanto, 2013), yang menjelaskan bahwa CSR menghasilkan do'a bagi perusahaan yang menjalankannya dengan kontinyu dan ikhlas. Hal ini terjadi karena pihak yang menerima CSR mempunyai tanggung jawab moral untuk mendoakan perusahaan pemberi CSR agar dapat terus berkembang dan bertambah besar dan inilah yang telah dilakukan oleh BMT Sidogiri. 


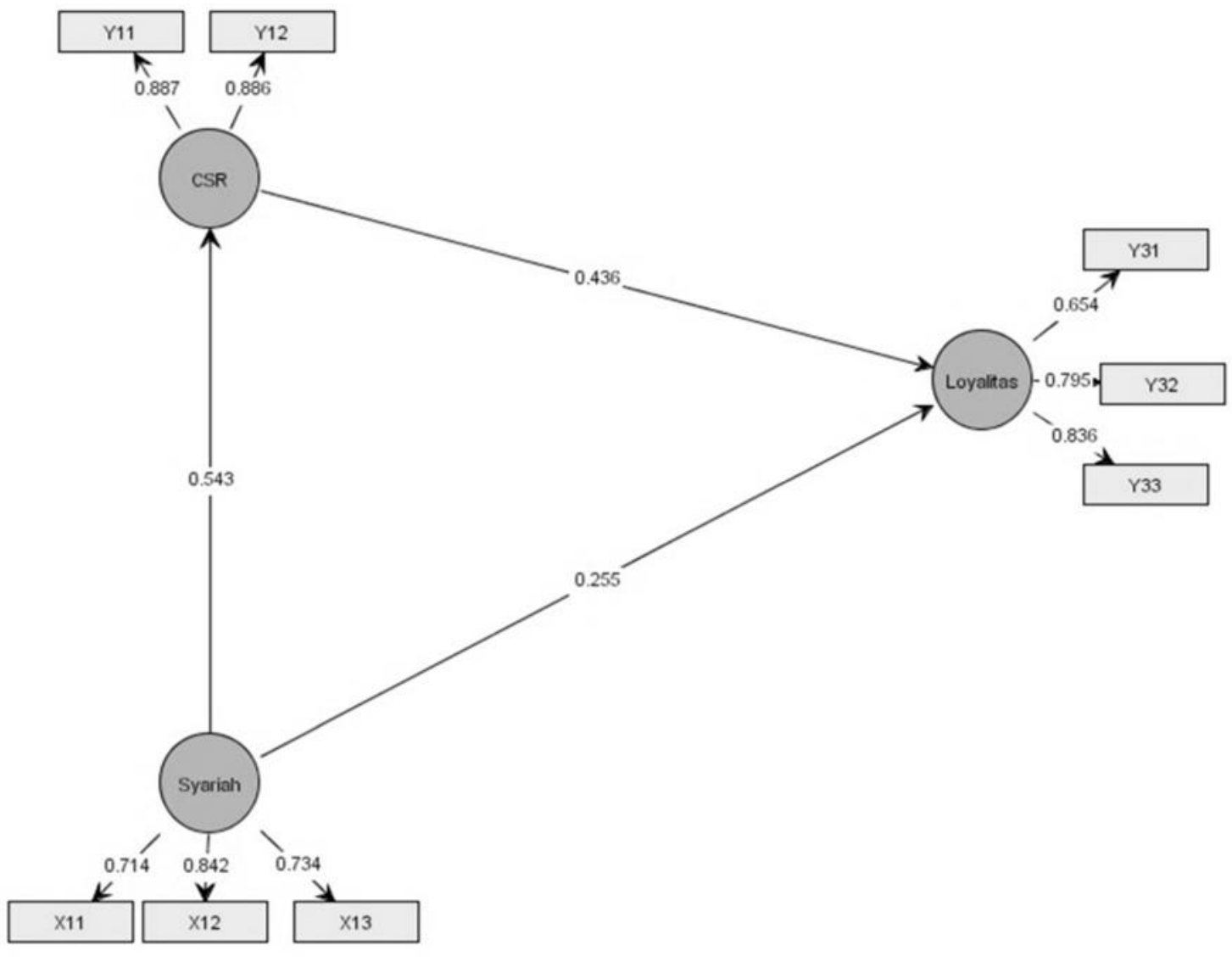

Gambar 4

Hubungan Tidak Langsung Antara KPS terhadap Loyalitas dengan CSR sebagai mediasi Sumber: Hasil Olahan, PLS 2015

Untuk mendukung peran CSR sebagai variabel mediasi, maka bisa dilihat dari hubungan langsung antara Ketaatan pada prinsip syari'ah (KPS) terhadap loyalitas nasabah yang terbukti tidak signifikan. Hal ini menjelaskan bahwasanya loyalitas nasabah terbentuk tidak hanya semata-mata karena BMT menerapkan prinsip syari'ah pada operasional kerjanya, tetapi nasabah juga perlu "bukti" atau manfaat apa yang telah diberikan oleh BMT dengan diberlakukannya prinsip syari'ah pada nasabahnya. Disini, BMT Sidogiri sebagai lembaga keuangan mikro syari'ah telah menerapkan CSR (pemberian pinjaman kebajikan dan dukungan pada konsumen). CSR berupa pinjaman kebajikan yang diberikan kepada nasabah kurang mampu inilah yang mempunyai daya tarik tersendiri bagi nasabah dalam melakukan transaksi keuangan pada
BMT, sehingga nasabah merasa bahwa BMT Sidogiri merupakan BMT yang layak untuk dijadikan sebagai mitra atau tempat untuk melakukan transaksi keuangan dibanding lembaga keuangan lain. BMT Sidogiri dianggap telah mengintegrasikan prinsip syari'ah pada aspek bisnis yang telah dijalankannya. Fenomena ini, kalau dihubungkan dengan karakteristik responden yang sebagian besar berpenghasilan rendah antara 1-2 juta sebesar $44,1 \%$, berpendidikan SD sebesar $47,8 \%$ dan pekerjaan wiraswata sebesar 45,6\%, maka pemberian pinjaman kebajikan yang diberikan oleh BMT Sidogiri kepada nasabah ini sudah tepat sasaran dan sesuai dengan prinsip pemberdayaan masyarakat, yaitu memandirikan ekonomi masyarakat serta sesuai dengan tujuan BMT. Pemberian pinjaman kebajikan ini juga sesuai dengan yang disampaikan oleh Al- 
Zuhayli (2003) yang menegaskan prioritas pinjaman atas amal didasarkan pada hadist sahih dari Nabi Muhammad. Ini adalah riwayat pada otoritas 'Arras bahwa Rasulullah (saw) mengatakan:

"Pada hari sayanaik ke surga (Laylatulqadr), aku melihat tulisan dipintu surga yang berbunyi: "Setiap amal dihargai sepuluhkali lipatdan setiap pinjaman dihargai delapan belas kali'. Jadi, saya bertanya kepada malaikat, Jibril, mengapa pinjaman dihargai lebih dari amal? Malaikat itu menjawab, "Karena seseorang mungkin bertanya untuk amal ketika iatidak membutuhkannya, tetapi peminjam hanya meminjam pada saat membutuhkan."

Hal inilah yang menjadi dasar terbentuknya loyalitas nasabah pada BMT Sidogiri; yaitu melakukan suatu program yang sangat bermanfaat seperti CSR. Akan tetapi, ke depan BMT harus memperbaiki dan meningkatkan ketaatannya dalam menerapkan prinsip syari'ah, karena dalam pelaksanaannya BMT masih mengutamakan pencegahan larangan riba daripada gharar dan maysir seperti harapan nasabah. BMT Sidogiri telah berusaha keras dalam menjaga transaksi keuangannya agar terhindar dari riba, gharar maupun maysir. Adapun contoh tindakan yang sudah dilakukan oleh BMT dalam menghindari gharar dan maysir adalah memastikan bahwa uang pinjaman yang di dapat dari BMT tidak diselewengkan atau benar-benar digunakan sesuai dengan akad yang disepakati, juga memastikan barang yang diperjualbelikan oleh nasabah tidak mengandung unsur haram. Untuk menghindari uang pinjaman diselewengkan nasabah, maka karyawan BMT rela setiap hari mengunjungi nasabah, sehingga kondisi nasabah terkontrol, baik kemampuan dalam membayar maupun jenis usaha yang tengah dilakukan. Strategi-strategi yang telah dilakukan ini jika dihubungkan dengan karakteristik responden yang sebagian besar kalangan bawah, bisa dikatakan berhasil dengan baik dalam menjaga keberlanjutan CSR selama ini.
Lebih jauh bisa dikemukakan, bahwa ketatnya BMT Sidogiri dalam menjalankan prinsip syari'ah terbukti dengan terjaganya pinjaman kebajikan untuk terhindar dari unsur-unsur riba, gharar, dan maysir terbilang cukup berhasil. Hal ini bisa dibuktikan dengan indikator pertama dari CSR yaitu pinjaman kebajikan; dimana tidak dikenakannya tambahan jumlah pengembalian terhadap pinjaman kebajikan. Pinjaman kebajikan dikembalikan hanya pokoknya saja, pinjaman kebajikan hanya dikenai biaya administrasi, yang besarnya tidak lebih dari $1 \%$ dari jumlah pinjaman. Strategi ini membuat nasabah tidak mengalami kesulitan atau keberatan dalam mengembalikan pinjamannya. Dana yang telah dipinjam oleh nasabah terhindar dari kredit macet yang bisa mengakibatkan turunnya jumlah dana pinjaman kebajikan yang akan diberikan kepada nasabah lain. Tidak adanya kredit macet pada jenis pinjaman kebajikan, menjadikan dana pinjaman kebajikan lambat laun akan berkembang dan besar jumlahnya. Semakin taat BMT Sidogiri dalam menerapkan prinsip syari'ah dalam transaksi keuangannya, maka akan semakin besar pula dana CSR yang dapat diberikan oleh BMT Sidogiri terhadap nasabahnya.

Praktik pemberian pinjaman kebajikan ini sudah sesuai dengan pendapat Qardawi (1998) terhadap hadist yang artinya: "Setiap pinjaman yang mempunyai keuntungan adalah riba". Beliau menyebutkan bahwa riba adalah hadiah atau keuntungan yang ditentukan sebagai syarat dalam perjanjian yang sudah disepakati sebelumnya. Dengan demikian, pinjaman qardul hasan yang dijalankan oleh BMT Sidogiri tidak termasuk riba, karena dalam pelaksanaannya tidak mensyaratkan imbalan tertentu dalam kesepakan awal, dan ini sudah sesuai dengan syariat Islam atau prinsip-prinsip syari'ah.

Selanjutnya indikator kedua dari CSR yaitu keharmonisan hubungan dengan nasabah, dengan ketatnya BMT Sidogiri dalam menjalankan prinsip syari'ah, maka nasabah akan merasa dibina, dijaga dan diperhatikan dalam hal pelunasan pinjaman- 
nya. Hal ini menyebabkan hubungan antara nasabah dengan BMT terjalin dengan baik karena akan meminimalisir nasabah yang terlambat atau tidak bisa mengembalikan pinjamannya sesuai dengan akad yang telah disepakati. Jadi dengan semakin tertibnya nasabah dalam melunasi hutangnya, maka akan semakin baik hubungannya dengan BMT. Hasil penelitian ini memperkuat penelitian terdahulu dari Awan dan Bukhari (2011), yang menemukan bahwa loyalitas terbentuk tidak hanya dari ketaatan bank terhadap prinsip syari'ah, akan tetapi loyalitas juga terbentuk karena adanya alasan eko- nomi seperti kualitas jasa dan nilai lebih produk yang di tawarkan oleh bank. Pe- nelitian ini juga mendukung penelitian El Junusi (2009), yang menemukan bahwa komitmen agama berpengaruh terhadap loyalitas, dengan melalui mediator kepuas- an. Hasil penelitian ini juga sesuai dengan literatur dari Alma dan Priansa (2009) yang dimodifikasi oleh Suharto; dimana CSR terbentuk dari pengembangan pemahaman aqidah, syari'ah, akhlaq, dimana harta adalah milik Allah SWT.

Menurut buku ini CSR terbentuk karena keimanan manusia terhadap segala yang diperintahkan oleh Allah (aqidah, syari'ah, akhlaq, harta adalah milik Allah), sehingga segala bentuk tindakan yang dilakukan oleh manusia (organisasi) harus merujuk pada aturan-aturan yang telah dibuatNya. Dijelaskan, bahwa organisasi (yang didalamnya adalah manusia) harus mengintegrasikan aturan-aturan Allah itu dalam operasi bisnisnya. Seperti kepedulian terhadap sesama yang merupakan perintah Allah sebagai orang yang beriman, maka harus mengimplementasikan keimanan (aqidah), syari'ah, akhlaq, tersebut dalam kehidupan sehari-hari baik dalam ritual ibadah maupun bermuamalah seperti pada dunia bisnis. Konsep ini biasa disebut dengan corporate social responsibility (CSR). Dengan demikian, BMT Sidogiri telah membuktikan bahwa dengan mengimplementasikan aqidah, syari'ah, dan akhlaq dalam kehidupan bisnis mereka, BMT Sidogiri menjelma menjadi BMT yang berkembang melebihi harapannya.

\section{SIMPULAN DAN SARAN Simpulan}

Berdasarkan hasil pengujian hipotesis, dapat dikemukakan beberapa kesimpulan sebagai berikut: (1) Temuan dari penelitian ini membuktikan bahwa ketaatan pada prinsip syari'ah (KPS) dapat meningkatkan loyalitas nasabah BMT Sidogiri melalui CSR dan kepercayaan sebagai mediasi. Hal ini menjadi bukti barang siapa menjalankan perintah agama secara baik dan benar, maka Allah SWT memenuhi janjinya dengan keberkahan, dalam hal BMT Sidogiri mendapatkan loyalitas yang tinggi dari nasabahnya; (2) Hasil penelitian ini menunjukkan bahwa CSR secara nyata memberikan kontribusi dalam meningkatkan loyalitas nasabah. CSR bukan hanya menyangkut pemenuhan kewajiban secara hukum, moral dan aturan pemerintah, tetapi juga sebagai aplikasi akhlak dan perilaku sebagai seorang muslim sehingga CSR harus dipandang sebagai bentuk amal/sedekah yang harus selalu ditambah sebagai bentuk ketaatan manusia kepada Allah SWT; (3) Kepercayaan itu mempunyai peranan yang sangat penting dalam membentuk loyalitas nasabah, sehingga BMT yang dikelola dengan prinsip syari'ah harus berupaya meningkatkan kepercayaan masyarakat dalam segala keputusan dan strategi pengembangan usahanya. BMT harus menghindari riba, gharar dan maysir, selalu jujur dan menjaga transparansi dalam setiap transaksi keuangannya supaya kadar kepercayaan masyarakat terus meningkat; (4) Temuan penelitian ini membuktikan, baik CSR maupun trust itu sangat penting artinya bagi loyalitas nasabah, karena dengan menjalankan CSR yang merupakan simbol kedermawanan dan trust sebagai simbol kejujuran dan amanah, maka BMT mendapat kepercayaan dan loyalitas yang tinggi dari nasabahnya; (5) Hasil penelitian ini memberikan bukti secara empiris, bahwa loyalitas nasabah tidak 
hanya terbentuk dari aspek agama atau ekonomi saja, melainkan juga terbentuk dari tiga aspek yaitu agama, ekonomi dan sosial.

\section{Saran}

Berdasarkan hasil dan simpulan penelitian, dapat dikemukakan beberapa saran yang dapat direkomendasikan dalam penelitian ini, adalah: (1) Disarankan kepada pihak pimpinan BMT Sidogiri Jawa Timur untuk tetap menjalankan CSR seperti mempertahankan dan meningkatkan pemberian pinjaman kebajikan (qardul hasan) yang telah dilakukan selama ini, demikian pula hubungan dengan konsumen yang telah terjalin dengan baik selama ini juga perlu ditingkatkan. Ke depan, BMT Sidogiri perlu mengembangkan program-program CSR ke arah yang lebih baik lagi seperti memberikan pelatihan-pelatihan usaha berbasis syari'ah dan pendampingan terhadap pengusaha mikro, sehingga pemberdayaan yang dilakukan oleh BMT Sidogiri lebih bermanfaat bagi masyarakat banyak; (2) Untuk meningkatkan kepercayaan, pihak BMT Sidogiri disarankan untuk tetap menjaga dan meningkatkan perilaku ihsannya serta kredibilitasnya dimata nasabah, sehingga loyalitas nasabah BMT Sidogiri bisa dipertahankan dan ditingkatkan. Ke depan, BMT Sidogiri perlu meningkatkan kualitas pelayanan, integritas dan kinerjanya, agar BMT Sidogiri lebih berkembang lagi; (3) Hasil temuan ini memberikan masukan bagi pihak pimpinan BMT, bahwa untuk meningkatkan loyalitas nasabah selain menjalankan CSR dan menjaga kepercayaan nasabah. BMT juga dituntut menjalankan prinsip syari'ah dengan baik dan benar, sehingga pelaksanaan CSR dan kepercayaan nasabah tetap terjaga dengan baik, yang pada akhirnya bisa meningkatkan loyalitas nasabah.

\section{DAFTAR PUSTAKA}

Abdullah, D. V. dan K. Chee. 2012. Keuangan Syari'ah; Cara Mudah Memahami Prinsip, Praktik, Prospek, dan Keunggulan Keuangan Islam di Zaman Kita. Zaman. Jakarta.
Almossawi, M. 2009. Bank selection criteria employed by college students in Bahrain: an empirical analysis. International Journal of Bank Marketing 19(3): 115-25.

Awan, H. dan K. S. Bukhari. 2011. Customer's criteria for selecting an Islamic bank: evidence from Pakistan. Journal of Islamic Marketing.

Bravo, R. Teresa, M. and Pina, J. M. 2009. The role of bank image for customers versus non-customers. International Journal of Bank Marketing 27(4): 315-334

El-Junusi, R. 2009. Pengaruh Atribut Produk Islam, Komitmen Agama, Kualitas Jasa, Dan Kepercayaan Terhadap Kepuasan Dan Loyalitas Nasabah Bank Syari'ah (Pada Bank Muamalat Semarang). the 9th Annual Conference on Islamic Studies (ACIS).

Farook, S. Hassan, M.K. and Lanis, R. 2011. Determinants of corporate social responsibility disclosure: the case of Islamic banks. Journal of Islamic Accounting and Business Research 2(2): 114-141.

Fatmah. 2009. Perilaku Konsumen Muslim: Religious Motive dan Economic Motive dalam Proses Pengambilan Keputusan. Jurnal Fakultas Ekonomi Universitas Muhammadiyah Surabaya.

Hassan dan S. A. Latiff. 2009. Corporate social responsibility of Islamic financial institutions and businesses: Optimizing charity value. Humanomics 25(3): 177188.

Hegazy, I. 1995. An Empirical Comparative Study between Islamic and Commercial Banks' Selection Criteria in Egypt. International Journal of Commerce and management 5(3): 46-61.

Hascaryani. 2011. Metafora risk and Return Sebagai Dasar Pengembangan Baitul Maal Waat Tamwil (BMT) Yang Mandiri. Journal of Indonesian Applied Economics 5(1): 93-109.

Jazim A. A. 2009. Client of conventional and Islamic banks in Bahrain: How they choose which bank to patronize.

Lewis. 2001. Service Quality, an International Comparison Bank customer expec- 
tations and perceptions. Journal of Marketing Management 7: 47-62.

Maali, B. 2003. Social reporting by Islamic banks. Discussion papers in accounting and finance. University of Southampton, Southampton.

Hassan, M. 2007. People's Perceptions towards the Islamic Banking: A Fieldwork Study on Bank Account Holders' Behaviour in Pakistan. School of Economics. Nagoya City University. Japan.

Muchlis. 2011. Perilaku Menabung di Perbankan Syari'ah Jawa Tengah. Disertasi. Program Studi Doktor Ilmu Ekonomi UNDIP. Semarang.

Naser, K. Jamal, A. and K. Al-Khatif. 1999. Islamic banking: a study of customer satisfaction and preferences in Jordan. International Journal of Bank Marketing 17(3): 134-150.

Omer, H. S. H. 1992. The implications of Islamic beliefs and practice on the Islamic financial institutions in the UK: case study of Albaraka International Bank UK. unpublished PhD thesis. Economics Department. Loughborough University. Loughborough.

Poolthong, Y. and R. Mandhachitara. 2009. Customer expectations of CSR, Perceived Service Quality and brand effect in Thai retail banking. International Journal of Bank Marketing 27(2): 408-427.

Poolthong, Y. and R. Mandhachitara. 2011. A Model of Customer Loyalty and Corporate Social Responsibility. Journal of Service Marketing 25(2): 122-133.
Rivai, V. dan B. Alma. 2012. Islamic Banking and Finance, Dari Teori ke Praktik. BPFE. Yogyakarta.

Saad, A. M. dan Almossawi, M. 1997. Banking behavior of Islamic bank customers: perspectives and implications.

Sadeq, A. M. 2002. Islamic Ethics in Human Resource Management, Ethics in Business and Management: Islamic and Mainstream Approaches, Asean Academic Press, London. 285-302.

Ismoyo, S. 2006. Analisis Probabilitas Masyarakat Muslim Menabung pada Perbankan Syari'ah di Kota Semarang. Thesis. Magister Ilmu Ekonomi dan Studi Pembangunan. Program Pascasarjana Unversitas Diponegoro Semarang. Tidak dipublikasi.

Sjahdeini, M. N. 1999. Islamic banking: true modes of financing. New Horizon 109: 15-20.

Suharto, E. 2009. Pekerjaan Sosial di Dunia Industri: Memperkuat Tanggungjawab Sosial Perusahaan (Corporate Social Responsibility). Refika Aditama. Bandung.

Suharto, E. 2010. CSR dan Comdev, Investasi Kreatif Perusahaan Di Era Globalisasi. Alfabeta. Bandung.

Sulayman, A. H. 1976. The Economics of Tawhid and Brotherhood: Contemporary Aspects of Economic Thinking in Islam. American Trust Publications. Indianapolis. IN.

Tjiptono, F. 2000. Manajemen Jasa. ANDI. Yogyakarta. 